\title{
LIBERDADE RELIGIOSA E DIREITO FUNDAMENTAL À NÃO DISCRIMINAÇÃO EM RAZÃO DA ORIENTAÇÃO SEXUAL
}

\author{
Fabrício Veiga Costa \\ Universidade de Itaúna, Minas Gerais \\ fvcufu@uol.com.br

\section{Alisson Alves Pinto} \\ Universidade de Itaúna, Minas Gerais \\ alvespintomg@yahoo.com.br
}

\begin{abstract}
RESUMO: O objetivo da pesquisa é investigar a utilização dogmática do direito fundamental à liberdade religiosa como legitimador do discurso de ódio contra as minorias sexuais. A escolha do tema se justifica em razão da relevância teórica, prática e atualidade do debate, haja vista que o direito à diferença, como corolário da igualdade, dignidade humana e não discriminação devem ser os referenciais hermenêuticos de interpretação e aplicabilidade dos direitos fundamentais no Estado Democrático de Direito. Absolutizar o exercício da liberdade religiosa, utilizando-a como meio de reprodução do discurso de ódio contra minorias sexuais, constitui uma forma de utilização da ciência do direito para segregar, excluir e marginalizar pessoas que não aderem aos padrões binários de uma heteronormatividade compulsória. Por meio de pesquisa bibliográfica e documental - além de análises temáticas, teóricas, interpretativas, críticas e comparativas -, foi possível demonstrar e concluir que a decisão judicial brasileira que proibiu a apresentação de peça de teatro em que uma mulher trans protagoniza a pessoa de Jesus Cristo, assim como a decisão da Suprema Corte dos EUA que legitimou o direito de um homem confeiteiro se recusar a fazer um bolo de casamento para um casal gay, por razões religiosas, deixam claro o protagonismo e a discricionariedade judicial, visto que tais decisões pautam-se em razões metajurídicas e solipsistas para robustecer a reprodução estrutural do discurso de ódio contra as minorias sexuais.
\end{abstract}

PALAVRAS-CHAVE: Dignidade da pessoa humana. Liberdade de expressão religiosa. Princípio da Igualdade. Minorias sexuais. Binarismo.

\section{Religious freedom and fundamental right to non-discrimination on grounds of sexual orientation}

\begin{abstract}
The aim of the research is to investigate the dogmatic use of the fundamental right to religious freedom as a legitimizer of hate speech against sexual minorities. The choice of the theme is justified due to the theoretical, practical and current relevance of the debate, given that the right to difference, as a corollary of equality, human dignity and non-discrimination, must be the hermeneutic framework for the interpretation and applicability of fundamental rights in the field. Democratic state. Absolutizing the exercise of religious freedom, using it as a means of reproducing hate speech against sexual minorities, is a way of using the science of law to segregate, exclude and marginalize people who do not adhere to the binary standards of compulsory heteronormativity. Through bibliographic and documentary research, as well as thematic, theoretical, interpretative, critical and comparative analyzes, it was possible to demonstrate and conclude that the Brazilian judicial decision that prohibited the presentation of a play in which a trans woman plays the person of Jesus Christ, as well as the ruling by the US Supreme Court, which legitimized the right of a confectioner to refuse to make a wedding cake for a gay couple,
\end{abstract}


for religious reasons, makes clear the protagonism and judicial discretion, since such decisions are based on It is based on metajuridic and solipsistic reasons to strengthen the structural reproduction of hate speech against sexual minorities

KEYWORDS: Dignity of human person. Freedom of religious expression. Principle of equality. Sexual minorities. Binarism.

\section{INTRODUÇÃO}

O objetivo da presente pesquisa é problematizar a investigação cientifica dos limites jurídico-constitucionais do exercício do direito fundamental à liberdade de expressão, frente ao discurso de ódio praticado por razões religiosas em face de pessoas que expressam sua sexualidade de um modo considerado contrário aos dogmas de algumas religiões. A escolha do tema se justifica em razão de sua relevância teórica, prática e atualidade, especialmente em razão das premissas democráticas trazidas pela Constituição brasileira de 1988 no que atine à proteção integral da pessoa humana quanto à diversidade sexual.

Objetivando sistematizar o debate do tema proposto, desenvolveu-se inicialmente um estudo sobre o direito à diferença na Constituição brasileira de 1988, a dimensão teórico-interpretativa do direito fundamental à liberdade religiosa sob a perspectiva do Estado Democrático de Direito, o direito à livre orientação sexual como corolário da dignidade humana, a problemática do reconhecimento do discurso de ódio e a relevância do direito à liberdade de expressão no âmbito das relações privadas. Ou seja, o estudo da dignidade humana no contexto propositivo da ponderação de valores; o direito à diferença, previsto no texto da Constituição brasileira de 1988; o exercício da liberdade de expressão como corolário da dignidade humana; o discurso de ódio contra as minorias sexuais por razões religiosas e a problematização do debate acerca do exercício do direito fundamental à liberdade de expressão frente ao papel do Estado diante das relações privadas são questões aqui debatidas com o propósito de apresentar aporias, no sentido de evidenciar a relevância da discussão proposta.

O advento da Constituição brasileira de 1988, marcada pelo seu caráter garantista no que atine à efetividade dos direitos fundamentais, consagra, dentre seus fundamentos e referenciais hermenêuticos, o pluralismo político, a liberdade de expressão, a cidadania, a vedação de discriminações e a igualdade entre as pessoas quanto ao tratamento jurídico recebido pelo Estado, pela sociedade civil e pelas instituições públicas e privadas. A Constituição de 1988 instituiu não somente direitos e garantias fundamentais, mas todo um sistema garantista de proteção. Significa dizer que o ordenamento jurídico pátrio, além de respeitar os requisitos formais que o legitima, deverá ser coerente com os princípios e valores constitucionais a um só tempo. Nesse sentido, o garantismo se vincula à ideia de limitação do poder estatal, de modo a evitar ocorrências de arbitrariedades e um sistema de proteção de bens e direitos, estendendo-se a todas as pessoas indistintamente, não apenas àquelas afetadas diretamente pelo poder punitivo do Estado.

Entretanto, verifica-se a existência de diversos grupos de pessoas que são subjugados em relação a outros, em razão de suas diferenças étnicas, culturais, linguísticas, sexuais, dentre outras, o que culminou na criação de grupos minoritários que se encontram em situação desigual em relação a uma maioria que dita padrões universalizantes de condutas. A consequência dessa exclusão e marginalidade dos grupos minoritários é a ofensa da dignidade humana e a violação de direitos humanos, ressaltando-se que as violações por eles suportadas é extensa, incluindo-se tortura e maus-tratos, agressões sexuais e estupro, invasão de privacidade, detenção arbitrária, negação de oportunidades de emprego, educação e sérias discriminações em relação ao gozo de outros direitos humanos. Estas violações tornam-se ainda mais gravosas quando decorrentes de 
razões religiosas baseadas em questões relacionadas a gênero e sexualidade, já que as religiões podem influenciar seus participantes ao fornecerem princípios para a socialização e para a organização da sociedade, além de indicações para a vida cotidiana.

Com efeito, algumas instituições religiosas aceitam a prática homossexual, considerandoa natural, enquanto outras instituições a consideram pecaminosa. A partir disso, várias crenças contrárias a essa prática podem ser encontradas, assumindo que a homossexualidade é uma "doença" e pode ser curada ou que os desejos devem ser controlados - posições essas que divergem dos avanços alcançados, por exemplo, em níveis jurídicos e no campo da saúde. Desse modo, a concepção de cada religião sobre o tema poderá influenciar a vida de pessoas em razão da sua orientação sexual, que podem aceitá-la ou então buscar uma "cura" ou resolução para o "problema".

A Constituição brasileira de 1988 prevê a liberdade de expressão como sendo um direito fundamental e o seu exercício pode ser interpretado como sendo mais um importante mecanismo de defesa das minorias e da diversidade, pois, de certa forma, permite que estes grupos exerçam direitos que normalmente lhes são suprimidos ou mitigados por uma maioria que detém maior representatividade social e política. Por outro giro, ao passo que essa previsão constitucional permite a possibilidade de os grupos minoritários se expressarem livremente, ela também permite que a maioria dominante possa se valer destes mesmos mecanismos para legitimar seu poder, o que normalmente ocorre por meio de discursos de ódio.

O discurso de ódio visa estigmatizar uma pessoa ou grupo de pessoas, sendo que a vitimização é difusa. Quando um homossexual é ofendido por sua orientação sexual, todos os homossexuais são ofendidos. Assim, quando um negro é ofendido pelo simples motivo de ser negro, todos os negros são diretamente ofendidos. Considerando-se que o Brasil é um Estado laico e regido pelas liberdades públicas e privadas, ele deve, portanto, oferecer a todos os cidadãos condições dignas para o exercício igual dos direitos. Ainda que a ideia de democracia não seja uniforme nem encerre em si uma única interpretação, é possível dizer que ela pressupõe uma ideia contrária à exclusão social de grupos minoritários, ressaltando-se que uma das funções primordiais do Estado Democrático de Direito é garantir o direito de as minorias gozarem dos bens jurídicos a ela disponibilizados no plano constituinte e instituinte. A pergunta problema que delimita o objeto da pesquisa é a seguinte: é possível harmonizar a liberdade religiosa com o livre exercício da orientação sexual numa perspectiva democrática proposta pela Constituição de $1998 ?$

Por meio de pesquisa bibliográfica e documental, foi possível apresentar fundamentos teóricos para legitimar cientificamente o debate proposto, especialmente no que tange aos limites do exercício das liberdades como meio de resistência e desconstrução do discurso de ódio. $\mathrm{O}$ método dedutivo foi utilizado para recortar a proposta de pesquisa, partindo-se de uma concepção macroanalítica, qual seja, o exercício do direito fundamental de liberdade de expressão, delimitando-se no estudo dos limites do exercício do respectivo direito como forma de desconstruir o discurso de ódio contra as minorias sexuais. A construção das análises temáticas, teóricas, interpretativas e comparativas foi de essencial importância para viabilizar a abordagem crítica do objeto de pesquisa, levantando-se novas questões para o desenvolvimento de outras investigações. 


\section{O DIREITO À DIFERENÇA SOBRE A ÓTICA DA CONSTITUIÇÃO DE 1988}

O respeito à diversidade, a superação da desigualdade historicamente estrutural e o compromisso com o projeto democrático de efetividade das normas constitucionais que colocam como centro de proteção jurídica a pessoa humana são algumas premissas essenciais para o entendimento crítico do objeto da presente pesquisa.

$\mathrm{O}$ direito à diferença exige reconhecimento das diferentes identidades dos sujeitos, enquanto o da igualdade traz em si a premissa de não discriminação ao que é diferente. A ética dos direitos fundamentais, que versa sobre o desenvolvimento da autonomia e respeito ao desenvolvimento das potencialidades humanas em suas mais diversas facetas, traz a concepção de que o ser humano é merecedor de igual respeito e consideração. (PIOVESAN, SILVA, 2008). Importante ressaltar que a violação dos direitos fundamentais ocorre em grande medida pela dificuldade de reconhecer o outro como igual em suas diferentes formas de ser, agir e se posicionar diante da vida. O temor ao diferente, que gera a dicotomia eu $x$ outro faz com que o distinto seja motivo para violar o outro em seus direitos e dignidade.

Nesse contexto propositivo, surgem as fases de proteção dos direitos fundamentais, ressaltando-se que a primeira é marcada pela proteção abstrata da igualdade formal das pessoas e a segunda se refere à proteção à diversidade dos seres humanos:

Torna-se, contudo, insuficiente tratar o indivíduo de forma genérica, geral e abstrata.
Faz-se necessária a especificação do sujeito de direito, que passa a ser visto em sua
peculiaridade e particularidade. Nessa ótica, determinados sujeitos de direito ou de-
terminadas violações de direitos exigem uma resposta específica e diferenciada. Vale
dizer, na esfera internacional, se uma primeira vertente de instrumentos internacio-
nais nasce com a vocação de proporcionar uma proteção geral, genérica e abstrata,
refletindo o próprio temor da diferença, percebe-se, posteriormente, a necessidade de
conferir a determinados grupos uma proteção especial e particularizada, em face de
sua própria vulnerabilidade. Isso significa que a diferença não mais seria utilizada
para a aniquilação de direitos, mas, ao revés, para sua promoção (PIOVESAN, 2005,
p. 46).

A primeira fase se caracteriza pela ideia mais genérica de que todos os seres merecem igual proteção. O direito à igualdade é consagrado no preâmbulo da Declaração Universal dos Direitos Humanos de 1948, assim como no corpo da Constituição da República Federativa do Brasil de 1988. Verificada a particularidade de cada ser humano, a segunda fase já coloca o direito à diferença como fundamental, de modo que a proteção ao diverso é ressaltada. Ademais, ao assumir o direito à igualdade como imanente a todos os cidadãos, o direito à diferença acaba sendo um fator de enriquecimento dessa igualdade. O reconhecimento da diversidade coloca todos os indivíduos na mesma posição (com os mesmos direitos e liberdades), de modo que a dicotomia eu x outro não enalteça e tampouco subjugue ninguém (PIOVESAN; SILVA, 2008). Nesse sentido:

\footnotetext{
Enquanto a igualdade pressupõe formas de inclusão social, a discriminação implica violenta exclusão e intolerância à diferença e diversidade. Assim, a proibição da exclusão, em si mesma, não resulta automaticamente na inclusão. Logo, não é suficiente proibir a exclusão, quando o que se pretende é garantir a igualdade de fato, com a efetiva inclusão social de grupos que sofreram e sofrem um consistente padrão de violência e discriminação. (PIOVESAN; SILVA, 2008, p. 12).
}

O desafio quanto à igualdade passa diretamente pela efetividade e concretude das premissas trazidas pelo texto da Constituição de 1988. A norma jurídica em si não é suficiente para romper com as estruturas históricas que naturalizam essa desigualdade estrutural quanto às questões de gênero, embora represente significativa contribuição no que atine à ressignificação de 
todo o contexto de reprodução vegetativa da condição desigual assumida e vivenciada por muitos sujeitos. O pensamento de Boaventura de Souza Santos vai ao encontro dos objetivos da segunda fase:

[...] temos o direito a ser iguais quando a nossa diferença nos inferioriza; e temos o direito a ser diferentes quando a nossa igualdade nos descaracteriza. Daí a necessidade de uma igualdade que reconheça as diferenças e de uma diferença que não produza, alimente ou reproduza as desigualdades. (SANTOS; NUNES, 2003, p. 56).

O compromisso com a proteção da diversidade é um dos objetivos do Estado Democrático de Direito. A visibilidade das diferenças é o que leva à busca por uma sociedade igualitária, ou seja: com o reconhecimento da diferença entre as pessoas, é possível buscar um tratamento igualitário a todas. Em contrapartida, a tentativa de tratar da maneira igual aqueles que são diferentes contribui para o aumento da discriminação, haja vista que a norma jurídica deve ser o recinto para a proteção individualizada de grupos de sujeitos, de modo a protegê-los conforme suas demandas e necessidades. Nesse sentido:

[...] se torna legítimo pensar no reconhecimento da diferença e da peculiaridade de
uma minoria (negros, mulheres, deficientes, sem-terra...), mais do que na pressupo-
sição da igualdade genérica de todos (povo, cidadão). É recente, portanto, a percep-
ção de que a noção de igualdade faz sombra à possibilidade de um reconhecimento
da singularidade ou particularidade de cada qual. (BITTAR, 2009, p. 552).

No Brasil, a diferença tem sido fator de grande desigualdade social, pois, diante da realidade política, econômica e social, o diferente é motivo de discriminação. Romper com essas estruturas de naturalização de desigualdades vai além da simples alteração legislativa; exige novas formas de interpretar e aplicar as proposições normativas existentes:

\begin{abstract}
O Brasil possui uma identidade cultural híbrida (CANCLINI, 2001) ante a pluralidade. Historicamente, a diferença no país tem sido motor da desigualdade social. As dinâmicas culturais estão entrecruzadas com as realidades políticas, econômicas e sociais. O imaginário incrustado na diferença resulta numa sociedade desigual e injusta. (CARDOSO, 2003). Isso porque a diferença passou a significar desigualdade, exclusão. (CANCLINI, 2001; CARDOSO, 2003 apud MELO, 2017, p, 91).
\end{abstract}

A partir do entendimento de que um tratamento homogeneizante com pessoas desiguais é insuficiente para atender aos anseios sociais, o tratamento jurídico do direito à diferença no Brasil tem se modificado. Nesse sentido, a Constituição brasileira de 1988 traz a ideia de pluralismo e incentiva a participação dos mais diversos grupos na política nacional. Diante desse cenário, nota-se que a ideia de um Estado Democrático de Direito, proclamado pela Constituição de 1988 (BRASIL, 1988), apresenta destaque especial ao princípio da dignidade humana e à igualdade material no exercício dos direitos fundamentais.

Ressalta-se, ainda, o total destaque dado ao (super) princípio da dignidade da pessoa humana, que emerge como maior fundamento do Estado Democrático de Direito, ocupando o lugar de destaque antes dado ao princípio da legalidade. Tal tendência não é um fenômeno isolado, tendo sido verificado de forma geral ao redor do mundo, como parte da renovação constitucional impulsionada pelo pós-guerra e pelas discussões em torno da terceira geração dos direitos fundamentais. (FARIAS, 2015, p. 26).

$\mathrm{O}$ direito à diferença se traduz em uma luta pelo reconhecimento das classes minoritárias da sociedade, que, dentro da dicotomia eu $x$ outros, constantemente são prejudicadas. "Nesse contexto, ocorre a afirmação da urgência de reconhecimento das necessidades não apenas da ampla coletividade, mas dos grupos minoritários que compõem o tecido social, dando-lhes proteção e visibilidade" (FARIAS, 2015, p. 26). Esse reconhecimento da diversidade humana, por ser uma manifestação latente da proteção aos direitos fundamentais, acaba se tornando um dos valores constitutivos da ideia de justiça social, ao lado da igualdade. Ou seja, o que é único não pode ser comparado nem classificado, tampouco visto como igual ou desigual (HELLER, 1998). 
E, junto à ideia de justiça social, a sociedade contemporânea, em razão de sua pluralidade, tem como forte característica a luta pelo reconhecimento e igual tratamento de todos os cidadãos na medida de suas diferenças. Para Habermas, "as condições concretas de reconhecimento, seladas por uma ordem jurídica legítima, resultam sempre de uma 'luta por reconhecimento' (HABERMAS, 2003, p. 168-9).

Na visão de Farias (2015), a tutela do direito à diferença ocorre em três eixos: repressivo, inclusivo e preventivo. Repressivo, na medida em que as normas punitivas servem para tutelar as identidades individuais e grupais, servindo o direito penal como instrumento para promover a cidadania. Como exemplo de atuação desse eixo, menciona-se a Lei 7.716/1989 (BRASIL, 1989), que trata dos crimes resultantes de preconceito por raça, cor, etnia, credo ou nacionalidade (FARIAS, 2015). Preventivo, com a utilização de políticas públicas, tal como a educação, voltadas para a defesa dos direitos humanos, partindo-se do pressuposto de que o auxílio no reconhecimento do que é dignidade, assim como no exercício da cidadania, são capazes de promover a dignidade dos indivíduos (FARIAS, 2015). O eixo inclusivo, por sua vez, consiste em ações do poder público ou privado que, por meio de ações afirmativas, buscam orientar os cidadãos quanto à solução das situações de desigualdade já existentes, visando ao desfazimento de exclusões históricas. Ações desse eixo encontram-se, por exemplo, nas políticas públicas voltadas ao público LGBTQI+ e às minorias historicamente marginalizadas, bem como nas cotas raciais para ingresso na educação de nível superior, também adotadas em concursos públicos (FARIAS, 2015).

Ante todo o exposto, nota-se que o direito à diferença está necessariamente atrelado à liberdade individual, de tal modo que cada ser humano seja capaz de se autodeterminar em suas mais diferentes singularidades. Nesse sentido, a liberdade individual se manifesta como um direito capaz de contribuir para a 'luta do reconhecimento' na sociedade contemporânea. Resta saber os limites de sua manifestação por cada indivíduo, para evitar que esse direito, em vez de dar voz às minorias, oprima-as com mais veemência.

\section{O DIREITO À LIBERDADE RELIGIOSA SOB A PERSPECTIVA DO ES- TADO DEMOCRÁTICO DE DIREITO}

O exercício das liberdades individuais e coletivas no Estado Democrático de Direito exige o respeito, o reconhecimento e a proteção integral de premissas genéricas e individualizantes hábeis para assegurar a igualdade e a dignidade da pessoa humana em seu mais alto espectro. Nesse sentido, a religião é vista como o complexo de princípios que dirigem pensamentos, ações e adoração do homem a Deus - o que compreende a crença, o dogma, a moral, a liturgia e o culto. Dessa forma, a religião pode ser vista e compreendida como o sistema de crenças que se vincula a uma divindade, que professa uma vida além da morte, que possui um texto sagrado, que envolve uma organização e que apresenta rituais de oração e adoração. Assim, a religião se relaciona diretamente com os assuntos mais básicos e importantes da vida de uma pessoa, traduzindo os seus valores mais íntimos e a sua crença em algo que tem significado último e genuíno.

No entanto, há quem enxergue a religião somente sob um aspecto negativo. Independentemente do conceito que se adota, contudo, não há dúvida de que a religião, direta ou indiretamente, sempre fez parte da vida, influenciando e modificando a história da Humanidade. A religiosidade é algo intrínseco à natureza humana, seja pessoa rica ou pobre, douta ou ignorante, do Norte ou do Sul; todos pensam ou vivem algo que se liga ao sobrenatural ou ao divino. Como fenômeno que penetra nas esferas mais íntimas da consciência humana e, simultaneamente, manifesta-se em grandes movimentos coletivos, o fenômeno religioso tem tido sempre importantíssima projeção política e jurídico-política, influindo constantemente não só na história cultural, 
mas também na história política. Nenhuma constituição deixa de o considerar também o direito internacional o repercute. Diversas são as religiões existentes em todo o mundo, conforme a época, cultura, origem, contexto social, político e histórico do lugar. Esses fatores condicionam ou determinam o relacionamento entre o Estado e a religião, podendo haver entre eles identificação, não identificação ou oposição.

De todas as religiões, o cristianismo se destacou no cenário mundial, assumindo um papel de divisor de águas sob vários aspectos. O valor da liberdade, assim como a dignidade da pessoa humana, assume destacada importância com o cristianismo. O fato de o filho de Deus ter vindo para trazer libertação confere a todos o sentimento de possuir uma liberdade irrenunciável e que nenhum poder, político ou social, pode violá-la. Após anos de perseguição aos judeus e cristãos, Roma - Império dominante da época - juntou-se a eles, sob o lema de que, se não pode contra eles, juntem-se a eles, decretando o cristianismo a religião oficial do império. A religião, assim, continuava ligada ao Estado, de forma que ou o Estado controlava a religião ou a religião controlava o Estado. A conquista da liberdade religiosa, todavia, começa com a quebra da unidade cristã a partir do século XVI, com a Reforma Protestante, conforme ensinou Jorge Miranda:

\begin{abstract}
A quebra da unidade da Crístandade, a Reforma e a Contra-Reforma abriram profundas fissuras individuais e políticas, perseguições e guerras político-religiosas que, num contexto de intolerância e absolutismo, acabariam por conduzir à regra de em cada Estado uma religião, a do Príncipe (Cujos Regio Ejus Religio). Todavia, também a muitos mostraram que a possibilidade de professar sem constrangimentos a sua própria fé e de praticar os respectivos actos de culto era algo de insubstituível que, quando posto em causa, poderia ser procurado noutras terras: foi o que aconteceu no século XVII na América do Norte. (MIRANDA, 2011, p. 121).
\end{abstract}

Apegando-se a esses acontecimentos da história do homem, não se pode deixar de observar que os direitos fundamentais, especialmente o direito à liberdade, na condição de direito positivado vinculativo, teve justamente sua origem em ideias religiosas, como afirma Jorge de Miranda: "a liberdade religiosa pode ser considerada um termômetro de medição da efetividade dos direitos fundamentais. Em muitos países, ela é ainda desconsiderada ou até mesmo negada" (MIRANDA, 2011, p. 120). Como consequência disso, verifica-se nesses países que vinculam religião ao constitucionalismo a inefetividade ou inexistência de direitos fundamentais básicos. Cita-se, como exemplo, a realidade dos países islâmicos, nos quais o Estado se confunde com a religião. Neles, nem sempre há igualdade entre homens e mulheres, bem como entre muçulmanos e não muçulmanos, e também muitas vezes não se admite liberdade fora do contexto religioso e político. O grau de liberdade religiosa de um Estado traduz o regime político adotado. Assim, só se encontram regimes políticos liberais, pluralistas e democráticos onde há plena liberdade religiosa, fundada nas premissas racionais que direcionam o entendimento da ciência do Direito.

Sem plena liberdade religiosa em todas as suas dimensões - compatível com diversos tipos jurídicos de relações das confissões religiosas com o Estado -, não há plena liberdade cultural, nem plena liberdade política. Assim, onde falta liberdade política, a normal expansão da liberdade religiosa fica comprometida ou ameaçada. Tal afirmação se justifica porque a liberdade religiosa - como uma faceta do princípio da liberdade - tem como objetivo concretizar o princípio da dignidade da pessoa humana. Segundo Rui Barbosa: "de todas as liberdades sociais, nenhuma é tão congenial ao homem, e tão nobre, e tão frutificativa, e tão civilizadora, e tão pacífica, e tão filha do Evangelho, como a liberdade religiosa" (1940, p. 50).

A liberdade de religião é, portanto, um direito fundamental que consiste na liberdade de pensamento e de consciência, de livre escolha de expressão, de manifestação e de culto. Falar em liberdade religiosa também é falar em direito de o Estado abster-se de impor ao foro íntimo do crente uma religião oficial; é falar em direito a não ter ou ter uma religião, segundo a sua livre 
escolha, e poder professá-la. As autoridades públicas, portanto, em face desse direito fundamental à liberdade religiosa, ficam impedidas de proibir o livre exercício de qualquer religião ou mesmo de impor qualquer limitação. Além do aspecto negativo, ou seja, da abstenção do Estado na esfera de escolha do crente, o direito à liberdade religiosa também implica em uma ação positiva por parte do Estado em garanti-lo e proporcioná-lo, seja por meio de leis ou outro meio que impeça o cerceamento de direitos ou quaisquer discriminações. Como exemplo de garantias constitucionais asseguradas pelo Estado, encontram-se, no direito comparado, aquelas realizadas pelos Estados Unidos da América:

\footnotetext{
I - Estabelecem um sistema, não meramente de tolerância, mas de igualdade religiosa. Todas as religiões são respeitadas, igualmente, pela lei, não devendo favorecerse uma em detrimento das outras, nem qualquer distinção entre elas, já nas leis, já na situação delas em face da lei, já na administração desta.

II - isentam todas as pessoas de contribuições compulsórias para manutenção de qualquer culto religioso, e da assistência compulsória ao mesmo.

III - Proíbem que sejam impostas restrições ao livre exercício da religião, segundo os ditames da consciência, e às livres manifestações das ideias religiosas (DWORKIN, 2006b, p. 88).
}

O Brasil é considerado um país laico ou não confessional, ou seja, não há qualquer relação entre o Estado brasileiro e a religião, consagrando-se a liberdade e igualdade de todas as religiões e a busca pela convivência harmônica entre as diferentes manifestações de crença. Com efeito, a Constituição da República Federativa do Brasil de 1988, no inciso VI do seu artigo $5^{\circ}$, protege o direito individual de crença religiosa, garantindo a inviolabilidade da liberdade de consciência e de crença, sendo assegurado o livre exercício dos cultos religiosos e garantida, na forma da lei, a proteção aos locais de culto e às suas liturgias.

O reconhecimento da liberdade religiosa pela Constituição denota haver o sistema jurídico que toma a religiosidade como um bem em si mesmo, como um valor a ser preservado e fomentado. Afinal, as normas jusfundamentais apontam para valores tidos como capitais para coletividade, que devem não somente ser conservados e protegidos, como também promovidos e estimulados. O dispositivo do art. 5º inciso VI, da Constituição de 1988 é norma de eficácia plena e imediata. É chamada pela doutrina de norma de direito fundamental sem expressa previsão de reserva legal, ou seja, o constituinte, diante da importância da liberdade religiosa, não previu a possibilidade de intervenção legislativa, restringindo ou disciplinando tal direito. Contudo, há posicionamentos jurídicos no sentido de defender que a colisão entre a liberdade religiosa e demais direitos fundamentais ou outros valores jurídicos protegidos pela Constituição justificaria excepcionalmente o estabelecimento de restrições a essa liberdade.

De fato, o direito à liberdade religiosa não pode ser invocado para se opor irrestritamente ao cumprimento das leis. Por exemplo, não se pode praticar ilícito alegando liberdade religiosa. Tal direito, como todos os demais direitos fundamentais, não é absoluto e, por isso, não se pode exercer um direito quando se viola o direito de outrem.

A efetividade constitucional do direito fundamental à liberdade de religião, crença ou religiosidade no Estado Democrático de Direito exige uma compreensão sistemática no contexto da dignidade humana, ressaltando-se que qualquer interpretação segregacionista utilizada para discriminar ou excluir pessoas deve ser refutada pelas premissas racionais e críticas preconizadas pelo constitucionalismo democrático. No próximo tópico, discorrer-se-á acerca do direito à livre orientação sexual e o seu papel fundamental no exercício da dignidade humana. 


\section{O DIREITO À LIVRE ORIENTAÇÃO SEXUAL E SEU PAPEL FUNDA- MENTAL NO EXERCÍCIO DA DIGNIDADE HUMANA}

O direito fundamental à liberdade de escolha e autodeterminação é corolário da dignidade humana e igualdade. Importante ressalta que "uma das principais objeções contra a ideia de um direito geral de liberdade é aquela que afirma que um tal direito seria vazio de conteúdo, sem substância, e que não haveria, por isso, nenhum parâmetro para decidir sobre a admissibilidade de restrições à liberdade" (ALEXY, 2018, p, 345). "Na verdade, liberdade e igualdade não estão em conflito, mas são princípios que se complementam, se pressupõem mutuamente" (OMMATI, 2018, p. 64). Nesse sentido, reconhecer juridicamente a dignidade de as pessoas serem livres constitui requisito essencial para implementar a igualdade material.

O direito ao livre desenvolvimento da personalidade constitui uma das principais formas de externalização da autonomia privada, conferindo ao seu titular a faculdade de autodeterminarse, de escolher a forma como exercerá os direitos previstos no plano legislativo, até mesmo de assegurar-lhe a faculdade de se abster de exercê-los, garantindo ao indivíduo a capacidade de decidir, por si só e livremente, sobre o exercício do direito, sem qualquer espécie de vinculação de natureza heterônoma, desde que não contrárias aos direitos de terceiros ou à ordem pública. Traduz-se, portanto, na faculdade de que gozam os indivíduos do direito de atuar de acordo com seu peculiar modo de ser, colocando em prática suas diferenças pessoais.

Nesse sentido, deve ser assegurada ao indivíduo a possibilidade de ser dono de seu próprio projeto de vida ou mesmo a possibilidade de sequer possuir um projeto de vida, bem como mudá-lo quantas vezes desejar, garantindo-lhe a liberdade necessária para desenvolver sua personalidade e se realizar como ser único e intangível. A partir da interpretação sistemática e extensiva do princípio da dignidade humana, fundada em parâmetros racionais de uma hermenêutica discursiva, busca-se a preservação do maior número de liberdades individuais sem que umas prejudiquem outras. Dessa forma, resguarda-se o exercício igual dos direitos fundamentais a todos os indivíduos, para que possam exercer suas liberdades sem a ingerência do Estado. A interpretação da dignidade humana fora da moldura democrática da constitucionalização dos direitos fundamentais não pode ser utilizada como forma de mitigação dos direitos das minorias e perpetuação dos valores universalizantes impostos pela maioria. Ou seja, os critérios interpretativos da dignidade humana não podem legitimar o discurso de ódio decorrente da imposição de comportamentos e ideologias para a sociedade, pressupondo a homogeneização de modus de vida. A dignidade humana, quando efetivada, objetiva fortalecer a autonomia privada, garantir o empoderamento de cada sujeito, assegurar a igualdade de aceitação de cada indivíduo no âmbito de suas escolhas individuais, sem qualquer interferência indevida e abusiva do Estado ou das demais instituições de controle da vida privada.

Nesse contexto propositivo, é importante ressaltar que Dworkin (2006) diferencia, em sua obra, "moralidade" e "ética". Para ele, a moralidade está relacionada à intervenção estatal, enquanto a ética diz respeito à liberdade alcançada por meio da autonomia privada de cada indivíduo. A intervenção moral do Estado, no campo da liberdade ética de exercício da autonomia privada, somente se justificaria quando comprovadamente o objetivo for proteger os direitos da coletividade. Algo distinto disso configuraria discurso de ódio, intolerância, preconceito e discriminação. Nota-se, portanto, que o princípio da dignidade está relacionado intrinsecamente à noção de liberdade, na medida em que a mais alta manifestação da dignidade ocorre quando o ser humano é, na sua singularidade, livre para se manifestar em suas mais diferentes crenças, ideias, jeito de ser, pensar, agir e se construir como pessoa humana. A igualdade quanto ao exercício digno da liberdade de expressão pressupõe ruptura com os juízos apriorísticos, fundados 
em máximas generalizantes que não respeitam as diferenças, visto que esses padrões universais retroalimentam o discurso segregacionista que enaltece a exclusão e a marginalidade de pessoas.

Os sujeitos políticos do movimento LGBTQI+ possuem uma diversidade de questões envolvidas, predominantemente relacionadas a gênero e à sexualidade. No curso da história, os indivíduos que possuíam essas diferenças em relação à maioria dominante foram rechaçados, tendo direitos humanos básicos tolhidos ou mitigados - e, até hoje, eles possuem dificuldades quanto ao exercício do direito fundamental ao livre desenvolvimento de sua personalidade. Lamentavelmente, a persecução da dignidade humana nem sempre foi algo permitido a esses grupos. Nesse sentido:

\begin{abstract}
[...] violações de direitos humanos que atingem pessoas por causa de sua orientação sexual ou identidade de gênero, real ou percebida, constituem um padrão global e consolidado, que causa sérias preocupações. O rol dessas violações inclui execuções extrajudiciais [sic.], tortura e maus-tratos, agressões sexuais e estupro, invasão de privacidade, detenção arbitrária, negação de oportunidades de emprego e educação, e sérias discriminações em relação ao gozo de outros direitos humanos. Estas violações são com frequência agravadas por outras formas de violência, ódio, discriminação e exclusão, como aquelas baseadas na raça, idade, religião, deficiência ou status econômico, social ou de outro tipo. (CORRÊA, MUNTARBHORN, 2006, p. 7)
\end{abstract}

O preconceito que segrega este grupo minoritário é algo estrutural. As formas como as sociedades modernas se estruturam em torno de questões religiosas, somado à falta de conhecimento acerca do tema, fazem com que os parâmetros socialmente aceitáveis sejam essencialmente preconceituosos, o que acaba por legitimar discursos contrários à diversidade sexual. Os movimentos sociais favoráveis à comunidade LGBTQI+, no mundo ocidental, são vistos como um tema político de esquerda, típico de partidos mais liberais e, dentre seus principais objetivos, encontra-se a ruptura com o binarismo e a heteronormatividade compulsória. Entretanto, existem movimentos sociais contrários e favoráveis às minorias sexuais, tanto em partidos mais conservadores quanto nos liberais - além de inúmeras religiões serem espaços utilizados para a perpetuação estrutural da segregação sexual. É importante consignar que, dentre as minorias que mais sofrem atualmente em virtude do discurso de ódio, destacam-se justamente as minorias sexuais, submetidas a essa forma de violência em todo o mundo, em menor ou em maior grau. Políticos e, sobretudo, líderes religiosos, têm se manifestado veementemente no sentido de que os direitos LGBTQI+ não devem ser reconhecidos e respeitados. Tais discursos utilizam-se, com frequência, de argumentos de impacto na psicologia individual e coletiva dos interlocutores, de modo a segregar socialmente tais indivíduos. Assim, exercem forte influência na opinião dos brasileiros, o que coloca mais obstáculos à luta das minorias sexuais pela afirmação de seus direitos no país.

Em razão da dor, sofrimento e tratamento desigual por motivo de orientação sexual, o movimento LGBTQI+ se levantou na luta em favor de seus direitos, recebendo cada vez mais o apoio do governo e de diversos segmentos da sociedade civil. A garantia do livre exercício da sexualidade relaciona-se com os postulados da liberdade individual, da igualdade social e da solidariedade humana. Além do princípio da dignidade da pessoa humana, outros princípios que repudiam a discriminação atentatória e o preconceito estrutural sobre a orientação sexual e a identidade de gênero são o princípio da não discriminação e o princípio da igualdade. O princípio da não discriminação é corolário do princípio da igualdade e determina que o pleno exercício dos direitos e liberdades fundamentais pertence a todas as pessoas, ou seja, deve existir uma igualdade de tratamento de todo ser humano, independentemente de raça, nacionalidade, língua, etnia, cor, sexo, religião ou condição social. A Constituição federal, em seu artigo $5^{\circ}$, inciso XLI, dispõe que a lei punirá qualquer discriminação atentatória dos direitos e liberdades fundamentais, determinando, assim, a proibição da discriminação como bem jurídico a ser tutelado. 
A liberdade, de modo geral, está estritamente relacionada à autonomia, ao direito de escolha e à legitimidade conferida a cada sujeito de direito de gerir sua própria existência em conformidade com seus ideais e perspectivas de vida. Em se tratando de liberdade sexual, refere-se à liberdade de escolher com quem se relacionar afetivamente. É um direito que deve ser tutelado e reconhecido pelo Estado. Quando o Estado nega ao indivíduo o reconhecimento e tutela deste direito, inibe-o de viver plenamente de acordo com a sua orientação sexual, com os seus anseios. Impossibilita o indivíduo de constituir uma família nos moldes que lhes é pertinente, limitando a sua realização pessoal. A liberdade é um direito que tem como objetivo dar aos homens a garantia de não perecerem nas mãos de tiranos ou na arbitrariedade de seus governantes. No entanto, além dos governos de muitos países, a própria sociedade e a religião interferem na vida sexual e reprodutiva da sociedade, isso por causa de um contexto histórico forte e enraizado em muitos países (CORRÊA). Tal situação leva pessoas a se filiarem a paradigmas que geram atos que atentam contra os direitos individuais e humanos. Por certo, a liberdade desenvolve inúmeros outros direitos, os quais são imprescindíveis para que a parte mais vulnerável da sociedade, no que tange a pessoas com orientações sexuais diferentes, possam pleitear seus direitos e a sua dignidade (RIOS, 2006).

Os direitos que abarcam a sexualidade se encontram atualmente em desenvolvimento e amadurecimento no cenário internacional - e, segundo os princípios da Yogyakarta, muitos Estados avançaram na concepção de direitos que tanto protegem o direito à sexualidade e a seu exercício de forma livre quanto, da mesma forma, reforçam a tutela dos direitos humanos (ORGANIZAÇÃO DAS NAÇÕES UNIDAS). Nessa seara, Kant estabelece como imperativo categórico a liberdade do homem, que, para ser realmente livre, necessita de condições para exercer essa liberdade, que nada mais são do que os direitos fundamentais e a dignidade da pessoa humana - condições estas que devem ser proporcionadas pelo Estado (KANT apud KUMAGAI; MARTA, 2010). A liberdade à determinação da sexualidade de cada pessoa denota semelhança com a tese de Kant para a formação da dignidade do ser humano, pois, em ambas as situações, a autonomia do indivíduo se torna a pedra angular que endossa sua escolha. No caso da dignidade, pelo prisma da autonomia, o homem "é capaz de autodeterminar-se e agir conforme as regras legais [...]" (KANT apud KUMAGAI; MARTA, 2010). A sexualidade, por este mesmo prisma, concretiza-se pela livre escolha do indivíduo, no que tange a suas decisões e a como esta pessoa levará sua vida sexual e afetiva, fazendo escolhas conforme suas próprias convicções, como aponta o direito à autonomia sexual (WAS, 2000).

Nesse sentido, os direitos sexuais vão além da forma com que a pessoa realizará sua sexualidade: tratam também da necessidade da prevenção de doenças e do direito de qualquer pessoa à saúde, independentemente de sua orientação sexual (ORGANIZAÇÃO DAS NAÇÔES UNIDAS). Da mesma forma para com a educação, que deve ser proporcionada a todos, com a meta de afastar a ignorância e o preconceito e, assim, fazer com que as pessoas entendam e respeitem umas às outras, sob as determinações dos diretos humanos e sexuais (ORGANIZAÇÃO DAS NAÇÕES UNIDAS). Enfim, a tutela dos direitos sexuais faz parte da realização do mínimo existencial, pois a positivação sobre estes direitos proporciona isonomia quanto ao tratamento estatal durante a distribuição destes bens, protegendo-os. Proporcionar o mínimo de forma abstrata pode não ser possível; porém, o Estado não pode ignorar os próprios princípios constitucionais, muito menos ignorar os direitos fundamentais que tangem o assunto direito sexual. Portanto, a prestação do mínimo proporcionaria uma vida digna (WEBER, 2013) e, além disso, também traria o desenvolvimento de uma sociedade pautada na dignidade da pessoa humana e na pluralidade de pensamentos, observando-se as premissas propostas pelo Estado Democrático de Direito. 
Observa-se, pois, que o direito à liberdade de expressão, ao mesmo tempo em que busca a efetivação da dignidade humana - de acordo com a forma em que é interpretado e, por consequência, utilizado -, pode causar o efeito justamente contrário, com a mitigação da dignidade de quem é afetado pela liberdade de expressão de um terceiro. Nesse aspecto, é que se questionará até que ponto a liberdade de expressão deve ser preservada e a partir de que ponto se deve resguardar a dignidade da pessoa humana em detrimento da liberdade de expressão religiosa. Com efeito, mesmo vivendo em um Estado Democrático de Direito, é necessário observar o contexto plural da sociedade brasileira, devendo a liberdade de expressão estar amparada na alteridade e no respeito ao próximo. No próximo tópico, discorreremos acerca do discurso de ódio.

\title{
4. RECONHECIMENTO DO DISCURSO DE ÓDIO
}

O discurso de ódio é reflexo da naturalização das estruturas sociais de segregação, da marginalidade e da exclusão daqueles sujeitos que destoam das máximas universalizantes que preconizam a homogeneização de padrões de condutas supostamente legitimados pelo historicismo. Reconhecer um discurso de ódio em meio a manifestações de liberdade de expressão não é uma tarefa fácil. Afinal, o que distingue essas duas posições de fala é definido muitas vezes pela interpretação daquele que observa de fora o caso concreto. "[O discurso de ódio] consiste na manifestação de ideias que incitam à discriminação racial, social ou religiosa a determinados grupos, na maioria das vezes, as minorias. Tal discurso pode desqualificar esse grupo como detentor de direitos" (MEYER-PFLUG, 2009, p. 97). Ele representa, através das manifestações feitas tanto na esfera pública quanto na privada, a segregação a tudo e a todos aqueles que são diferentes. Nesse contexto, pode-se afirmar:

\begin{abstract}
[...] trata de perpetrar a marginalização ou subordinação das pessoas pertencentes ao grupo explorado, mediante o desprezo, ou inclusive o insulto [...]; sobretudo quando, na maior parte dos casos, se trata de traços pessoais que a pessoa afetada não pode trocar por sua própria vontade - a cor de sua pele ou seu sexo [...]. (CODERCH apud MEYER-PFLUG, 2009, p. 97).

Wienfried Brugger afirma que o mesmo discurso [de ódio] seria constituído por [...] palavras que tendam a insultar, intimidar ou assediar pessoas em virtude de sua raça, cor, etnicidade, nacionalidade, sexo ou religião, ou que têm a capacidade de instigar a violência, ódio ou discriminação contra tais pessoas (BRUGGER apud MEYERPFLUG, 2009, p. 97).
\end{abstract}

Como bem demonstrado nas citações acima, esses discursos são direcionados a grupos minoritários, na medida em que a característica que os diferencia dos demais gera repulsa e insatisfação. Essa repulsa vem do sentimento de raiva e de indignação que um indivíduo tem de o outro que não lhe é semelhante (em cultura, ideologia, aparência entre outros) poder gozar dos mesmos direitos e liberdades. $\mathrm{O}$ discurso de ódio tem suas bases no fato de pessoas não reconhecerem os demais sujeitos como iguais no que tange ao exercício dos direitos fundamentais. Com relação ao tema, ressalta-se:

[...] reconhecer os discursos de ódio como práticas argumentativas ancoradas em uma profunda busca de segregar o "estranho" e a sua "insuportável e indesejável diferença", como se este "outro estrangeiro" portasse alguma "doença contagiosa" da qual a sociedade precise ser "curada". Isto é, um discurso ofensivamente posto "para atacar o outro por causa de sua raça, etnia, religião ou identidade sexual". (SMOLLA, 1992, p. 151 apud PRATES, 2015, p. 91).

Percebe-se que os hate speeches estão vinculados, como uma radical contraposição à exigência e afirmação de novos direitos por parte de atores sociais antes vistos como observadores passivos do processo histórico de construção da sociedade, funcionando como perversas válvulas de escape que setores desta mesma sociedade empregam para tentar manter "tudo como sempre foi", sendo os cidadãos "pessoas como 
nós", ou seja, "a mixofobia se manifesta na tendência em direção a ilhas de similaridade e semelhança em meio a um oceano de variedade e diferença." (BAUMAN, 2007, p. 92-93 apud PRATES, 2015, p. 92).

Conforme exposto, as instituições democráticas buscam construir um espaço de diálogo, no qual as proposições teórico-legislativas se baseiem na opinião da maioria, mantendo-se o respeito e o tratamento igualitário conferido às minorias. Nesse ponto, alguns discursos devem ser limitados, para que essa defesa aos direitos fundamentais seja possível.

Saliente-se, assim, que as democracias constitucionais procuram configurar espaços abertos, não "tribais", em que o plural é constitutivo, entretanto, há discursos, que não obstante serem parte deste pluralismo, pregam, como dogmas de fé, a total exclusão do diferente, procurando fechar a própria identidade constitucional. (PRATES, 2015, p. 95).

Pela vasta pluralidade do Estado e a diversidade que marca a sociedade contemporânea, permitir manifestações sem que, contudo, essas violem direitos de outrem é uma tarefa árdua. A liberdade de não concordar, de não gostar e de não desejar qualquer tipo de contato com o diferente não pode gerar discursos inflamados e discriminatórios na seara pública, na tentativa de que adeptos dos mesmos ideais compartilhem e disseminem essa intolerância, visando à realização de algum ato que concretize o preconceito e coloque (mantenha) os diferentes em condição de inferioridade social. Nesse contexto, é importante esclarecer que o papel do Estado é garantir que essas minorias possam viver em paz nas suas relações privadas, com os mesmos direitos assegurados a todos, ainda que certos grupos majoritários não concordem com a existência e modo de vida dos minoritários. A desconstrução do discurso de ódio passa diretamente pelo fato de cada sujeito reconhecer seu interlocutor como igual, no que atine ao exercício e gozo de todos os direitos fundamentais previstos no plano constituinte e instituinte. E é nesse ponto que reside o discurso de ódio: quando um grupo que se vê superior a outro acredita e defende que a distribuição de direitos de forma igualitária fere e mitiga seus direitos individuais. No livro 'Liberdade para as ideias que odiamos', Anthony Lewis (2011) se manifesta sobre o tema nos seguintes termos:

\begin{abstract}
Discurso de ódio, é assim que ele é chamado: ataques virulentos a judeus, negros, muçulmanos, homossexuais ou membros de qualquer outro grupo. É ódio puro, não baseado em algum erro praticado por um indivíduo. No período do nazismo na Alemanha, um alemão podia ser um católico romano praticante; mas, se os nazistas descobrissem que ele tinha um avô judeu, lá ia ele para um campo de morte. (LEWIS, 2011, p. 187).
\end{abstract}

O ódio e a intolerância são reflexos de processos históricos que naturalizam o discurso homogeneizante de não aceitação daqueles indivíduos que pensam, agem e conduzem suas vidas de maneira distinta dos padrões genéricos impostos. Por isso, cabe ao Estado e a sociedade civil não se deixar levar pelos ideais preconizados pelos grupos majoritários, cumprindo seu papel de defesa e efetividade dos direitos fundamentais exercidos igualmente por todos os cidadãos, independentemente de raça, cor, crença, orientação sexual, condição social, entre outros. É importante mencionar que um dos argumentos a favor da permissão do discurso de ódio é que ele torna os indivíduos cientes de crenças terríveis e reforça a decisão de combatê-las. Esse argumento, todavia, foi contestado de forma dura por Jeremy Walderson, um inglês que emigrou para lecionar direito nos Estados Unidos. Deste modo, ele se expressa:

Os custos do discurso de ódio [...] não se disseminam por igual na comunidade que se supõe que deva tolerá-lo. Os [racistas] do mundo podem não causar danos às pessoas que dizem que eles devem ser tolerados, mas poucas delas são retratadas como animais em cartazes colados nas ruas de Lemington Spa [uma cidade inglesa]. Antes de concluirmos que tolerar esse tipo de discurso ajuda a construir o caráter, devemos falar com aqueles que são retratados desse modo, ou com aqueles cujo sofrimento, 
ou o sofrimento de seus pais, é ridicularizado pelos [neonazistas de Skokie]. (WALDRON, 2006, p. 22-23).

Pelo exposto até o momento, observa-se que o discurso de ódio tem suas raízes no nazismo, na intolerância do outro, pelo simples fato de não aderir às premissas homogêneas impostas pelo grupo dominante. Nesse sentido, as proposições legislativas trazidas pelo direito democrático, assim como seus métodos de interpretação, devem priorizar o reconhecimento igual de exercício de direitos fundamentais a todos os sujeitos, protegendo-os dentro de suas particularidades e reprimindo qualquer ato ou conduta contrária ao tratamento jurídico isonômico a ser assegurado a cada pessoa, já que isso é pressuposto para viabilizar sua dignidade humana no Estado Democrático de Direito. É por isso que se torna relevante o estudo do exercício do direito fundamental de liberdade de expressão no contexto das relações privadas - discussão essa construída no próximo tópico da pesquisa.

\section{LIBERDADE DE EXPRESSÃO, DISCURSO DE ÓDIO E O PAPEL DO ES- TADO NAS RELAÇÕES PRIVADAS A PARTIR DA ANÁLISE DE CASOS CONCRETOS}

Expostos os principais entendimentos quanto à dignidade humana, liberdade de expressão e discurso de ódio, propõe-se analisar dois casos - um, ocorrido nos Estados Unidos e outro, no Brasil -, cujos temas têm a ver com a discussão proposta neste trabalho. O primeiro caso diz respeito à decisão judicial proferida pelo juízo da 1 a $^{\mathrm{a}}$ Vara Cível da cidade de Jundiaí-SP, proibindo a exibição de uma peça de teatro que retrataria Jesus Cristo como travesti. Já o segundo versa sobre a recusa de um confeiteiro norte-americano de fazer um bolo de casamento para um casal homossexual. O objetivo do relato desses casos não é meramente reproduzir a decisão tomada pelos tribunais competentes, mas sim compreender e identificar quando o fato pode ser considerado liberdade de expressão religiosa ou um discurso de ódio na perspectiva de um Estado Democrático de Direito, contextualizando o estudo com o debate acerca do direito fundamental à liberdade sexual.

Em setembro de 2017, uma decisão judicial no Brasil proibiu a exibição de uma peça de teatro. Trata-se da peça $O$ Evangelho segundo Jesus, rainha do céu, que estrearia no Sesc em Jundiaí (SP), no dia 15 de setembro daquele ano, retratando Jesus Cristo como uma mulher transgênero nos dias atuais. A decisão foi do juiz Luiz Antônio de Campos Júnior, da $1^{\mathrm{a}}$ Vara Cível daquela cidade. Para ele, figuras religiosas e sagradas não podem ser "expostas ao ridículo" (BRASIL, VioMundo, 2017). Adaptado na obra da dramaturga inglesa Jo Clifford, o espetáculo se propõe a recontar passagens bíblicas sob uma perspectiva contemporânea e promover a reflexão sobre a opressão e a intolerância sofridas por transgêneros e minorias em geral, destacando que a mensagem cristã é de amor, perdão e aceitação. A ação contra o Sesc foi promovida pela advogada Virgínia Bossonaro Rampin Paiva, que alegou que a peça afeta a dignidade cristã, expondo ao ridículo símbolos religiosos como a cruz e a religiosidade que ela representa. $\mathrm{O}$ juiz de Jundiaí concordou com os argumentos da advogada e aceitou o pedido de antecipação de tutela, impondo multa de $\mathrm{R} \$ 1.000,00$ (mil reais) por dia de descumprimento. O magistrado considerou o espetáculo de mau gosto e explicou que sua intenção com a decisão é impedir um ato que maculará o sentimento do cidadão comum. Na sentença, o juiz, também faz questão de ressaltar que, no entendimento dele, não se trata de censura prévia e que não se pode confundir liberdade de expressão com agressão e falta de respeito. "Não se pode admitir a exibição de uma peça com um baixíssimo nível intelectual, que chega até mesmo a invadir a existência do senso comum, que deve sempre permear por toda a sociedade", escreveu (BRASIL, VioMundo, 2017). 
Os artistas da peça $O$ Evangelho segundo Jesus, rainha do céu lamentaram o cancelamento do espetáculo em sua página no Facebook. Afirmaram que o juiz atendeu a um pedido que vinha sendo articulado por congregações religiosas, por políticos e pela organização TFP (Tradição, Família e Propriedade). A proibição da exibição da obra prova a sua importância disseram os artistas -, lembrando que o Brasil é o país que mais assassina travestis e transexuais no mundo. "Abençoada sejas se abusam de você ou te perseguem. Isso significa que você está trazendo a mudança. E abençoados sejam aqueles que te perseguem também. O ódio é o único talento que têm e não vale nada", declararam os artistas (BRASIL, VioMundo, 2017). Por sua vez, a diretora e tradutora da peça, Natalia Mallo, classificou a decisão de Luiz Antônio de Campos Junior como um tratado de fundamentalismo e preconceito. "Censurar um espetáculo, em nome dos bons costumes, da fé e da família brasileira parece ser, para alguns fariseus, mais importante e prioritário do que olhar para a sociedade e tentar fazer alguma contribuição concreta para mudar o quadro de violência em que estamos todas e todos soterrados. Inconformado com a decisão liminar de primeira instância, o Sesc recorreu para garantir a exibição do espetáculo, que provoca reflexões em torno de questões de gênero. Ao analisar o recurso interposto pelo Sesc, o egrégio Tribunal de Justiça de São Paulo revogou a liminar que proibia a exibição da peça. Para o relator do acórdão, desembargador José Luiz Mônaco da Silva, a proibição feriu de morte a atividade artística da atriz transgênera que interpreta o personagem bíblico Jesus Cristo. Pode-se até não concordar com o conteúdo da peça, mas isso não é motivo suficiente para alguém bater às portas do Judiciário para impedir a sua exibição. Basta não assistir ao espetáculo, ressaltou (BRASIL, VioMundo, 2017). Na decisão, o relator salientou ainda que a peça tem caráter ficcional e objetiva fomentar o debate sobre os transgêneros, sem ultrajar a fé cristã.

Com visto, a Constituição brasileira de 1988, sobretudo em seu artigo $5^{\circ}$, assegura diversos direitos e garantias fundamentais, como o direito à igualdade e à liberdade de expressão. Entretanto, ainda existem situações de violações, cuja mera invocação desses dispositivos não é capaz de solucionar as recorrentes violações de direitos humanos que afetam as minorias sexuais. Tal afirmação se justifica em razão da necessidade de compreender que a implementação efetiva do direito à igualdade de gênero e à liberdade de expressão passa pela reconstrução do processo histórico fundado na premissa de reconhecimento do outro como igual no que atine ao exercício dos direitos fundamentais previstos no plano constituinte e instituinte. A decisão do magistrado paulista de primeira instância reproduz as vozes das estruturas sociais de segregação e marginalidade sexual historicamente perpetrada contra a comunidade LGBTQI+, além de evidenciar com clareza o protagonismo e a discricionariedade judicial, fundada em parâmetros metrajurídicos utilizados para justificar supostamente a violação dos direitos fundamentais àqueles "ditos sujeitos" considerados inaptos ao gozo dos referidos direitos.

A falta de atuação do poder legislativo ou a dificuldade hermenêutica de se analisar a demanda dos grupos minoritários não pode servir de escudo protetor para que uma maioria dominante impeça determinados grupos de indivíduos de viverem dignamente. Não podem o judiciário, o Estado e a sociedade civil permitirem que a Constituição se torne um mero instrumento utilitarista a serviço de uma maioria dominante que reproduz as vozes de um discurso que exclui as minorias sexuais. Nesse sentido, evidentemente que a proibição do juízo de primeira instância de Jundiaí é um ato de transfobia. Ora, se Jesus é tido como imagem e semelhança de todo mundo, por que não o seria das pessoas trans? Diversas são as origens que tentam legitimar e explicar os discursos de ódio e incomensuráveis são os danos que estes podem causar, sobretudo em relação à comunidade LGBTQI+. Não se pode endossar a existência de discursos de ódio perpetrados pelo Estado ou por seus agentes, tampouco por uma maioria em face de uma minoria, visto que não se pode tolher o direito que os particulares possuem de se expressarem livremente no âmbito de sua sexualidade. O judiciário, assim como outras instituições, está vinculado ao princípio da supremacia das normas constitucionais frente às demais normas do ordenamento 
jurídico - o que é imprescindível para o Estado Democrático de Direito, vez que constitui garantia da soberania popular e da cidadania. As normas infraconstitucionais não podem ser contrárias às regras e princípios adotados pela Constituição, a fim de coibir excessos e abusos de poder, bem como assegurar o respeito aos direitos constitucionais e ao regime político democrático adotado.

É importante ressaltar que a peça teatral censurada pelo juízo de Jundiaí-SP tem como objetivo desconstruir o preconceito histórico que marginaliza travestis e transexuais e faz do Brasil o país que mais mata membros dessa comunidade. Ao destacar a identidade travesti como elemento chave da dramaturgia e da encenação, o trabalho convida o espectador a refletir sobre a discriminação e a invisibilidade dos grupos socialmente marginalizados e a transformar o olhar por meio de mensagens de amor e perdão. Por meio da função contra majoritária, os direitos fundamentais servem justamente como uma proteção em face da vontade de uma maioria, o que significa dizer que eles existem para conter a maioria. E essa contenção ocorre quando a Constituição determina os meios para se evitar a imposição da dita vontade majoritária, principalmente quando a dogmatização da vontade majoritária é utilizada para segregar, excluir e marginalizar as minorias sexuais. Nesse sentido, os direitos humano-fundamentais devem proteger pluralmente não só a maioria dos cidadãos, mas todos os indivíduos, até aqueles que compõem grupos sociais minoritários, pois o objetivo do constitucionalismo é harmonizar esses ideais de democracia e de direitos fundamentais até um ponto de equilíbrio no qual repousa a dignidade da pessoa humana. Passemos à análise do segundo caso, ocorrido no Estados Unidos da América.

Em suma, refere-se a um confeiteiro religioso que, por razões de sua crença, se negou a confeccionar o bolo de casamento de um casal homossexual. Levada a se manifestar, a Suprema Corte decidiu que a negação era lícita, em observância à primeira emenda e ao direito à liberdade de expressão e ao livre exercício da religião.

\begin{abstract}
Masterpiece Cakeshop, Ltda., é uma padaria do Colorado de propriedade e operada por Jack Phillips, um padeiro especialista e cristão devoto. Em 2012 ele disse a um casal do mesmo sexo que ele não criaria um bolo para a festa de casamento por causa de sua oposição religiosa aos casamentos entre pessoas do mesmo sexo - casamentos que o Colorado não reconhecia -, mas que ele iria vendê-los outros produtos de panificação, por exemplo, bolos de aniversário. O casal registrou uma acusação com a Comissão de Direitos Civis do Colorado (Comissão) em conformidade com a Lei Anti-Discriminação do Colorado (CADA), que proíbe, como relevante aqui, a discriminação baseada na orientação sexual em um "local de negócios envolvido em qualquer venda ao público e qualquer lugar que ofereça serviços para o público". De acordo com o sistema de revisão administrativa da CADA, a Divisão de Direitos Civis do Colorado primeiramente encontrou uma causa provável de violação e remeteu o caso à Comissão. A Comissão então submeteu o caso para uma audiência formal perante um Juiz de Direito Administrativo estadual (ALJ), que decidiu a favor do casal. Ao fazê-lo, o ALJ rejeitou a utilização da Primeira Emenda por Phillips: exigir que ele crie um bolo para um casamento do mesmo sexo violaria seu direito à liberdade de expressão, obrigando-o a exercer seus talentos artísticos para expressar uma mensagem com a qual ele discordou e violaria seu direito ao livre exercício da religião. Tanto a Comissão e o Tribunal de Apelações do Colorado afirmaram [o direito de Phillips]. (SUPREMA CORTE DOS EUA, 2017, p. 1, tradução nossa).
\end{abstract}

É importante consignar que o tribunal reverteu a decisão sobre a Masterpiece com base em questões exclusivas do caso, mas reafirmou sua antiga regra de que os estados devem prevenir dados da discriminação no mercado, inclusive contra pessoas LGBTQI+. Para o caso em tela, duas importantes previsões legais entram em choque: o direito à livre manifestação ou expressão religiosa e o dever de não discriminação em virtude de orientação sexual. Ao receber a negativa para a confecção do bolo, o casal homossexual se sentiu discriminado e afirmou uma intolerância por parte do confeiteiro. Ocorre que a alegação de intolerância por parte do confeiteiro pode ser analisada também em relação ao casal homossexual, que não soube respeitar a crença religiosa 
de Phillips (o confeiteiro). Assim, em vez de tratar da intolerância de ambas as partes, o parecer do Tribunal afirma que se deve buscar a tolerância entre ambas, visando à dignidade de todas.

\begin{abstract}
O resultado de casos como este em outras circunstâncias deve aguardar uma maior elaboração nos tribunais, tudo no contexto de reconhecer que essas disputas devem ser resolvidas com tolerância, sem desrespeito indevido a crenças religiosas sinceras, e sem submeter pessoas gays a indignidades quando buscar bens e serviços em um mercado aberto, afirma o parecer. (VOGUE, 2018, s./p. tradução nossa).
\end{abstract}

Nesse sentido, a decisão do Tribunal se pautou em uma ponderação de valores e direitos, ao passo que buscou o equilibrio entre as dignidades, tanto do casal gay, em não ser discriminado pela orientação sexual, quanto do confeiteiro, em ser respeitado em sua crença religiosa. Nesse contexto de liberdades e de ponderação, a lei antidiscriminação foi interpretada para o caso concreto, de modo que se chegou à conclusão de que o devido dispositivo legal tão somente obriga o confeiteiro a não discriminar um terceiro em razão de sua orientação sexual, mas não o força a apoiar um ato do qual discorda.

\begin{abstract}
Mullins e Craig entraram com uma queixa junto à Comissão de Direitos Civis do Colorado, que decidiu em seu favor, citando uma lei estadual anti-discriminação. Phillips levou seu caso ao Tribunal de Apelações do Colorado, argumentando que exigir que ele fornecesse um bolo de casamento para o casal violou seu direito constitucional à liberdade de expressão e ao livre exercício da religião. $\mathrm{O}$ tribunal considerou que a lei anti-discriminação do Estado era neutra e geralmente aplicável e não obrigava a obra-prima de Phillips, Cakeshop, a "apoiar ou endossar qualquer visão religiosa particular". Ele simplesmente proibiu a Phillips de discriminar clientes em potencial por causa de sua orientação sexual. (VOGUE, 2018, s./p., tradução nossa).
\end{abstract}

Observa-se que o respeito de dois direitos, liberdade religiosa e não discriminação pela orientação sexual em um mesmo caso concreto, somente será possível com a utilização da técnica da ponderação e com a compreensão de que o não exercício pleno de um direito não implica necessariamente seu desrespeito. Na verdade, há uma sobreposição de direitos, de modo a preservar a dignidade de ambas as partes. Na perspectiva trazida pelo judiciário norte-americano, a dignidade do casal gay não foi em momento algum desrespeitada, mas para que o direito à liberdade religiosa também não o fosse, foi necessária a sobressalência desse segundo sobre o primeiro para o caso específico. Ou seja, a negação do confeiteiro não teve relação direta com o casal em razão de sua orientação sexual, mas sim com a crença religiosa particular do profissional. Melhor dizendo, significa que o ato de negar contribuir para a cerimônia gay diz mais respeito aos valores do confeiteiro - e, como ele iria lidar consigo mesmo, caso violasse tais valores - do que com o casal gay que solicitou a realização do serviço. Para a Suprema Corte, a atitude de negação não representa uma discriminação com o terceiro, mas sim seu respeito aos próprios valores, ainda que, de ricochete, o casal acabe sendo afetado. Nota-se, então, que o relevante, no caso concreto, foi a compreensão dos motivos do confeiteiro ao se negar a fazer o bolo, para que então a ponderação dos direitos fosse feita de modo adequado.

Ao analisar o respectivo caso sob a perspectiva da constitucionalidade democrática brasileira, verifica-se que se trata de mais um caso de institucionalização do discurso heteronormativo de naturalização de premissas segregacionistas perpetradas contra a comunidade LGBTQI+. Tal afirmação se sustenta porque justificar a discriminação sexual a partir da máxima da "ponderação de valores" constitui um meio de mascarar o discurso de ódio sexual, tornando-o subliminar, obscurecendo o preconceito, além de legitimar a desigualdade em razão da orientação sexual. 


\section{CONSIDERAÇÕES FINAIS}

As estruturas sociais vigentes naturalizam historicamente o discurso de segregação sexual, fundadas no binarismo e na heteronormatividade compulsória, ressaltando-se que dogmas e proposições religiosas são frequentemente utilizados como parâmetro para legitimar a manutenção da desigualdade de pessoas em razão de sua orientação sexual. Harmonizar a aplicabilidade do direito fundamental à liberdade religiosa, frente ao livre exercício da orientação e da dignidade sexual de pessoas, exige alteridade como forma de reconhecimento da igualdade material, corolários do princípio da não discriminação.

O presente artigo objetivou verificar se é possível conceder legitimidade aos discursos de ódio decorrentes de questões religiosas em face de grupos ditos minoritários, especialmente por razões de orientação sexual. A Constituição brasileira de 1988 , sobretudo em seu artigo $5^{\circ}$, assegura diversos direitos e garantias fundamentais, como o direito de igualdade e a liberdade de expressão. Entretanto, ainda existem situações de violações cuja mera invocação destes dispositivos não é capaz de solucionar as recorrentes ofensas aos direitos humanos que afetam as minorias sexuais. Tal afirmação se justifica em razão da necessidade de compreender que a implementação efetiva do direito à igualdade de gênero e à liberdade de expressão passa pela reconstrução do processo histórico fundado na premissa de reconhecimento do outro como igual no que atine ao exercício dos direitos fundamentais previstos no plano constituinte e instituinte.

A falta de atuação do poder legislativo ou a dificuldade hermenêutica de se analisar a demanda dos grupos minoritários não pode servir de escudo protetor para que uma maioria dominante impeça determinados grupos de indivíduos de viverem dignamente. Não podem o judiciário, o Estado e a sociedade civil permitirem que a Constituição se torne um mero instrumento utilitarista a serviço de uma maioria dominante, que reproduz as vozes de um discurso que exclui as minorias sexuais. Em relação aos discursos de ódio e a liberdade de expressão, entendeu-se que não seria recomendável a criação de uma legislação de oportunidade, haja vista que a abstração e subjetividades pertinentes ao tema podem ser resolvidas diante de uma interpretação racional e pormenorizada da estrutura estatal, além de que as soluções efetivas contra às discriminações negativas extrapolam a seara do direito ou até mesmo os limites da compreensão humana. Sistematizar uma legislação pautada em máximas generalizantes não resolverá a questão que envolve o discurso de ódio perpetrado contra a população LGBTQI+. É necessário reconstruir parâmetros hermenêuticos que conferem vozes a interpretação racional dos direitos fundamentais, pautados nas premissas da dignidade humana, igualdade e liberdade de expressão.

Diversas são as origens que tentam legitimar e explicar os discursos de ódio e incomensuráveis são os danos que estes podem causar, sobretudo em relação à comunidade LGBTQI+. Não se pode tolerar a existência de discursos de ódio perpetrados pelo Estado ou seus agentes, tampouco de uma maioria em face de uma minoria, visto que não se pode tolher o direito que os particulares possuem de se expressarem livremente no âmbito de sua sexualidade. Ainda que não seja possível encontrar um sentido único para a realidade social e o intérprete judicial possua certo grau de subjetividade na criação do entendimento jurídico, político e social, especialmente no tocante às normas constitucionais, não se pode olvidar que o constitucionalismo contemporâneo tem como característica fundamental o conteúdo aberto, com estabelecimento de princípios e diretrizes ao Estado, que, além de vincular o regime democrático, confere a ele um caráter antimajoritário. O judiciário, assim como os outros poderes, está vinculado ao princípio da supremacia das normas constitucionais frente às demais normas do ordenamento jurídico, o que é imprescindível para o Estado Democrático de Direito, vez que constitui garantia da soberania popular e de cidadania. As normas infraconstitucionais não podem ser contrárias às regras e princípios adotados pela Constituição, a fim de coibir excessos e abusos de poder, bem como assegurar o respeito aos direitos constitucionais e ao regime político democrático adotado. 
Como contraponto a estas situações de violação, cabe ao judiciário interpretar os princípios constitucionais e formular as respostas constitucionalmente mais adequadas, a fim de se resguardar as características de um Estado democraticamente estabelecido. Tal proposta pode ser interpretada como uma variante dos discursos perpetrados pela maioria dominante, como uma forma de autoritarismo, só que, desta vez, em favor de uma minoria. Entretanto, este não parece ser este o caso, pois a violação dos direitos de grupos minoritários, como a comunidade LGBTQI+, ultrapassa não somente os direitos e garantias fundamentais, pois violam a essência que o direito visa assegurar, qual seja, a dignidade da pessoa humana, que é o valor máximo no qual se sustenta todo o ordenamento jurídico pátrio.

Os direitos e garantias fundamentais - e até mesmo a democracia brasileira - possuem um caráter contramajoritário. Violar tais direitos é conspurcar a essência, é ir na contramão da organização social estabelecida pela Constituição brasileira de 1988. Uma das funções dos direitos fundamentais e da própria democracia é servir justamente de freio aos anseios da denominada maioria democrática, o que pode parecer um tanto quanto paradoxal, já que a democracia comumente é tida como o direito da maioria. Por meio da função contra majoritária, os direitos fundamentais servem justamente como uma proteção em face da vontade de uma maioria, o que significa dizer que eles existem para conter a maioria. E essa contenção ocorre quando a Constituição determina os meios para se evitar a imposição da dita vontade majoritária, principalmente quando a dogmatização da vontade majoritária é utilizada para segregar, excluir e marginalizar as minorias sexuais. Nesse sentido, os direitos humano-fundamentais devem proteger pluralmente não só a maioria dos cidadãos, mas todos os indivíduos, até aqueles que compõem grupos sociais minoritários, pois o objetivo do constitucionalismo é harmonizar esses ideais de democracia e direitos fundamentais até um ponto de equilíbrio no qual repousa a dignidade da pessoa humana.

Por isso, conclui-se que tanto a decisão judicial que proibiu a apresentação da peça de teatro retratando Jesus Cristo na pessoa de uma mulher trans quanto a decisão da Suprema Corte autorizando um confeiteiro a se recusar a fazer um bolo de casamento para um casal gay ilustram que se encontra institucionalizado o discurso de ódio entre muitos magistrados, que - utilizando argumentos metajurídicos, solipsistas e axiologizantes - fortalecem o protagonismo judicial e endossam o discurso binário-heteronormativo, que segrega e exclui pessoas em razão da orientação sexual.

\section{REFERÊNCIAS}

ALEXY, Robert. Teoria dos direitos fundamentais. 2. ed. São Paulo: Malheiros, 2018.

BARBOSA, Rui. Obras completas. Rio de Janeiro: MEC/Casa de Rui Barbosa, 1940. 50 Tomos.

BARBOSA, Rui O Papa e o Concílio. Rio de Janeiro: MEC, 1977.

BARBOSA, Rui. Queda do Império. Diário de Noticias. Rio de Janeiro: MEC, 1947, Vol. 16, t. 1.

BERNARDES, Cláudio Márcio; MORAIS, Márcio Eduardo Senra Nogueira Pedrosa. O ensino domiciliar como expressão da liberdade religiosa no estado democrático de direito. Universitas Jus, Brasília, v. 27, n. 3, p. 145-155, 2016.

BITTAR, Eduardo C. B. Reconhecimento e direito à diferença: teoria crítica, diversidade e a cultura dos direitos humanos. São Paulo: Rev. da Faculdade de Direito da Universidade de 
São Paulo. v. 104. Jan/dez 2009. 551-565p. Disponível em: https://www.revistas.usp.br/rfdusp/ article/view/67869. Acesso em: 01 maio 2019.

BOBBIO, Norberto. A era dos direitos. Rio de Janeiro: Campus, 2018.

BORELLA, François. Le Concept de Dignité de la Personne Humaine. In: PEDROT, Philippe (Dir.). Ethique Droit et Dignité de La Personae. Paris: Economica, 1999.

BRASIL. Constituição da República Federativa do Brasil. Brasília: [s.n]. 1988. Disponível em: http://www.planalto.gov.br/ccivil_03/constituicao/constituicaocompilado.htm. Acesso em: 01 maio 2019.

BRASIL. VioMundo. Disponível em https://www.viomundo.com.br/denuncias/censura-juizproibe-a-peca-evangelho-segundo-jesus-rainha-do-ceu-minutos-antes-de-comecar-no-sesc-jundiai.html. Acesso em $01 \mathrm{dez} .2019$.

BRASIL. TJ/SP. Processo Digital n. 1016422-86.2017.8.26.0309. Relator: Juiz de Direito Luiz Antônio de Campos Júnior.

BRASI. Lei 7.716, de 05 de janeiro de 1989. Define os crimes resultantes de preconceito de raça ou de cor. Brasília: DOU. Disponível em: http://www.planalto.gov.br/cciv il 03/leis/17 716. htm. Acesso em: 31 maio 2019.

CANOTILHO, J. J. Gomes. Direito constitucional. São Paulo: Almedina, 2018.

CASTILHO, Ricardo. Direitos humanos: processo histórico - evolução no mundo, direitos fundamentais: constitucionalismo contemporâneo. São Paulo: Saraiva, 2017.

COMPARATO, Fábio Konder. A afirmação histórica dos direitos humanos. 11. ed. São Paulo: Saraiva, 2017.

CORRÊA, Sonia Onufer; MUNTARBHORN, Vitit. Princípios de Yogyakarta. Disponível em: http://www.clam.org.br/uploads/conteudo/principios_de yogyakarta.pdf. Acesso em: 30 set. 2019.

DALLARI, Dalmo de Abreu. Direitos humanos e cidadania. São Paulo: Moderna, 2004.

DIMOULIS, Dimitri; MARTINS, Leonardo. Teoria geral dos direitos fundamentais. 6. ed. São Paulo: Revista dos Tribunais, 2018.

DWORKIN, Ronald. A virtude soberana: a teoria e a prática da igualdade. Tradução de Jussara Simões. São Paulo: Martins Fontes, 2005.

DWORKIN, Ronald. Casos Difíceis. In: Levando os Direitos a Sério. Tradução de Nelson Boeira. São Paulo: Martins Fontes, 2002.

DWORKIN, Ronald. Is democracy possible here? Principles for a new political debate. Princeton: Princeton University Press, 2006a.

DWORKIN, Ronald. O direito da liberdade: a leitura moral da Constituição norteamericana. Trad. Marcelo Brandão Cipolla. São Paulo: Martins Fontes, 2006b.

FARIAS, Camilo de Lélis Diniz de. A nova ordem constitucional e a tutela do direito à diferença. Revista Direito e Liberdade, Natal, v. 17, n. 1, p. 11-33, jan./abr. 2015. Quadrimestral. Disponível em: http://www.esmarn.tjrn.jus.br/revistas/index.php/revista_direito_e liberdade/article/ view/718/641. Acesso em: 01 jun. 2019.

FARIAS, Edilsom Pereira de. Liberdade de expressão e comunicação: teoria e proteção constitucional. São Paulo: Revista dos Tribunais, 2004. 
FELDMAN, David. Human dignity as a legal value - part I. [S.l]: Public Law, 2000.

FREITAS, Riva Sobrado de; CASTRO, Matheus Felipe de. Liberdade de Expressão e Discurso do Ódio: um exame sobre as possíveis limitações à liberdade de expressão. Florianópolis: Sequência, n. 66, jul. 2013. p. 327-355. Disponível em: http://www.scielo.br/pdf/seq/n66/14.pdf. Acesso em: 01 mai. 2019.

HÄBERLE, Peter. Hermenêutica constitucional: a sociedade aberta dos intérpretes da Constituição: contribuição para a interpretação pluralista e "procedimental" da Constituição. Porto Alegre: Sergio Antonio Fabris Editor, 1997.

HABERMAS, Jürgen. Direito e democracia: entre facticidade e validade. Tradução de Flávio Beno Siebeneicher. v. 2. Rio de Janeiro: Tempo Brasileiro, 2003.

HABERMAS, Jürgen. Mudança estrutural da esfera pública: investigações quanto a uma categoria da sociedade burguesa. Rio de janeiro: Tempo Brasileiro, 2003.

HELLER, Agnes. A condição política pós-moderna. Tradução Marcos Santarrita. Rio de Janeiro: Civilização Brasileira, 1998.

HOMER, Chris; WESTACOTT, Emrmys. O conceito de religião. Disponível em: http://www. pensamentocritico.com/index.php?option=com content\&task=view\&id=54\&Itemid=29.

Acesso em: 23 out. 2019.

JUBILUT, Liliana Lyra; BAHIA, Alexandre et al. Direito à diferença. 1. ed. São Paulo: Saraiva, 2014.

KANT, Immanuel. Fundamentação da metafísica dos costumes e outros escritos. São Paulo: Martin Claret, 2011.

LEWIS, Anthony. Liberdade para as ideias que odiamos. São Paulo, Aracati, 2011.

MARX, Karl. Religião. Disponível em: http://br.geocities.com/fusaobr/religiao.html. Acesso em: 28 out. 2019.

MENDES, Gilmar Ferreira; COELHO, Inocêncio Mártires; BRANCO, Paulo Gustavo Gonet. Curso de direito constitucional. 11. ed. São Paulo: Saraiva, 2016.

MEYER-PFLUG, Samantha Ribeiro. Liberdade de Expressão e Discurso do Ódio. São Paulo: Revista dos Tribunais, 2009.

MILL, John Stuart. A Liberdade: Utilitarismo. [Clássicos] Tradução de Eunice Ostrensky. São Paulo: Martins Fontes, 2000.

MINHOTO, Antônio Celso Baeta et al. Constituição, minorias e inclusão social. São Paulo: Rideel, 2009.

MIRANDA, Jorge. Manual de direito fundamental. Tomo IV. Direitos Fundamentais. 9 ed. revista e atualizada. Coimbra: Coimbra, 2011.

MORAES, Alexandre de. Constituição do Brasil interpretada e legislação constitucional. 9. ${ }^{\text {a }}$ ed. São Paulo: Atlas, 2013.

MULLER, Friedrich. Quem é o povo? A questão fundamental da democracia. 5. ed. São Paulo: Revista dos Tribunais, 2010.

OMMATI, José Emílio Medauar. Uma teoria dos direitos fundamentais. 5.ed. Rio de Janeiro: Lumen Juris, 2018. 
ONU. Declaração Universal dos Direitos Humanos. [S.1.: s.n]. 1948. Disponível em: https:// www.ohchr.org/EN/UDHR/Pages/Language.aspx?LangID=por. Acesso em: 01 jul. 2019.

PIOVESAN, Flávia. Ações afirmativas da perspectiva dos direitos humanos. Cadernos de Pesquisa, São Paulo, v. 35, n. 124, p. 43-55, jan./abr. 2005.

PIOVESAN, Flávia; SILVA, Roberto B. Dias da. Igualdade e diferença: o direito à livre orientação sexual na Corte Europeia de Direitos Humanos e no Judiciário brasileiro. In: VIEIRA , José Ribas (Org.). 20 anos da Constituição cidadã de 1988: efetivação ou impasse institucional? Rio de Janeiro: Forense, 2008, 341-367p. Disponível em: https://www.passeidireto.com/ arquivo/6120552/igualdade-e-diferenca-flavia-piovesan-e-roberto-dias. Acesso em: 01 maio 2019.

PRATES, Francisco de Castilho. As fronteiras da liberdade de expressão no estado democrático de direito: o desafio de falas que oprimem, de discursos que silenciam. 2015. Tese (Doutorado em Direito) - Curso de Pós-Graduação em Direito, Universidade Federal de Minas Gerais. Minas Gerais. 345p. Disponível em: http://www.bibliotecadigital.ufmg.br/dspace/ bitstream/handle/1843/BUBD-A3XFBS/ppgdireito_franciscocastilhoprates tesedoutorado.pdf? sequence $=1$. Acesso em: 01 maio 2019.

RAMOS, André de Carvalho. Curso de direitos humanos. 4. ed. São Paulo: Saraiva, 2017.

REALE JÚNIOR. Limites à liberdade de expressão. Revista Espaço Jurídico, Florianópolis: v. 11, n. 2, p.; 374-401, jul./dez. 2010.

RIDOLA, Paolo. A dignidade da pessoa humana e o "princípio liberdade" na cultura constitucional europeia. (Trad. Carlos Luiz Strapazzon). Porto Alegre: Livraria do Advogado, 2014.

ROSA, Leonardo Gomes Penteado. O liberalismo igualitário de Ronald Dworkin: o caso da liberdade de expressão. 2014. Dissertação (Mestrado em Direito) - Curso de Pós-Graduação em Direito, Universidade de São Paulo. São Paulo.253p. Disponível em: https://www.teses.usp. br/teses/disponiveis/2/2139/tde-20012015-163906/publico/dissertacao_leonardogomespenteadorosa.pdf. Acesso em: 01 maio 2019.

ROSENFELD, Michel. Hate Speech in constitutional jurisprudence: a comparative analysis. In: Cardozo Law School (Working Paper Series). [on line]. n. 41, ab. 2001. Disponível em: https://papers.ssrn.com/sol3/papers.cfm?abstract id=265939. Acesso em: 30 abr. 2019.

SANTOS, Boaventura de Souza; NUNES, João Arriscado. Introdução: para ampliar o cânone do reconhecimento, da diferença e da igualdade. In: Reconhecer para Libertar: Os caminhos do cosmopolitanismo multicultural. Rio de Janeiro: Civilização Brasileira, 2003.

SANTOS, Gustavo Gomes da Costa. Diversidade sexual, partidos políticos e eleições no Brasil contemporâneo. In: Rev. Bras. Ciênc. Polít., n. 21, p. 147-186, 2016. Disponível em: http:// www.scielo.br/scielo.php?pid=S0103-33522016000300147\&script=sci_abstract\&tlng=pt.

Acesso em: 29 set. 2018.

SARMENTO, Daniel. A Liberdade de Expressão e o Problema do Hate Speech. Revista de Direito do Estado (RDE), Rio de Janeiro: ano 1, n. 4, out./dez. 2006. p. 53-105

SARLET, Ingo Wolfgang. Eficácia dos direitos fundamentais: uma teoria geral dos direitos fundamentais na perspectiva constitucional. 17. ed. Porto Alegre: Livraria do Advogado, 2018.

SILVA, José Afonso da. Curso de direito constitucional positivo. São Paulo: Malheiros, 2018.

SILVA, José Afonso da. Aplicabilidade da norma constitucional. 4. ed. São Paulo: Malheiros, 2000. 
SIMAO, José Luiz de Almeida; RODOVALHO, Thiago. A Fundamentalidade do Direito à Liberdade de Expressão: as justificativas instrumental e constitutiva para a inclusão no Catálogo dos Direitos e Garantias Fundamentais na Constituição Federal de 1988. Cadernos do Programa de Pós-Graduação em Direito - PPGDir./UFRGS, Porto Alegre, v. 12, n. 1, set. 2017. ISSN 2317-8558. Disponível em: https://seer.ufrgs.br/ppgdir/article/view/72978/43857. Acesso em: 01 jun. 2019.

SMOLLA, Rodney A. Free Speech in an open society. New York: Vintage, 1992.

STERN, Klaus. Das Staatsrecht des Bundesrepublik Deutschland. Munique: Allgemeine Lehren der Grundrechte, 1989. v. III/1. Supreme Court Of United States. Masterpiece Cakeshop, Ltd., et al. V. Colorado Civil Rights Commission et al. 2017. Disponível em: http:// cdn.cnn.com/cnn/2018/images/06/04/16-111_j4el.pdf. Acesso em 10 jun. 2019.

TÔRRES, F. C. O direito fundamental à liberdade de expressão e sua extensão. Revista de Informação Legislativa (RIL), Brasília, 50, n. 200, p. 61-80, out./dez. 2013. Disponível em: https:/ /www12.senado.leg.br/ril/edicoes/50/200/ril_v50_n200_p61.pdf. Acesso em: 02 maio 2019.

WALDRON, Jeremy. Boutique Faith. London review of books. Chicago. 20, julho, 2006. Disponível em: https://www.lrb.co.uk/v28/n14/jeremy-waldron/boutique-faith. Acesso em: 30 jun. 2019.

Submetido em: 8 dez. 2019.

Aceito em: 17 maio 2021. 